\title{
MENINGKATKAN KEMAMPUAN BERBICARA \\ DENGAN METODE DEBAT DALAM PROSES PEMBELAJARAN \\ BAHASA INGGRIS PADA PESERTA DIDIK KELAS VII C \\ SMPN 4 CIANJUR
}

\author{
Imas Sri Mulyani \\ SMPN 4 Cianjur \\ srimulyani_imas@yahoo.com
}

\begin{abstract}
Abstrak
Penelitian ini berangkat dari latar belakang kemampuan komunikasi bahasa Inggris masih rendah. Penyebab timbulnya masalah antara lain: (1) Sebagian peserta didik beranggapan bahwa bahasa Inggris merupakan mata pelajaran yang tidak menarik, sulit, dan membosankan. (2) Proses pembelajaran bahasa Inggris kurang kondusif dan inovatif dalam penyampaian pelajaran sehingga peserta didik tidak bisa menerima pembelajaran yang telah diberikan oleh gurunya dan mengakibatkan kemampuan serta hasil belajar bahasa Inggris tidak sesuai dengan yang diharapkan. (3) Rendahnya kemampuan berbicara bahasa Inggris peserta didik juga dikarenakan guru masih mengalami kesulitan dalam menyampaikan materi bahasa Inggris kepada peserta didik, (4) Kurangnya variasi dan inovasi guru dalam menggunakan media pembelajaran, teknik pembelajaran, metode pembelajaran, model pembelajaran, dan bahan ajar juga menyebabkan peserta didik kurang bergairah atau kurang semangat dalam menerima pelajaran. Salah satu model pembelajaran yang diharapkan dapat meningkatkan motivasi dan hasil belajar adalah dengan menggunakan metode pembelajaran debat. Metode debat merupakan salah satu metode pembelajaran yang sangat penting untuk meningkatkan kemampuan berbicara bahasa Inggris. Desain penelitian ini menggunakan model Kemmis dan Tagart dengan tahapan perencanaan, tindakan dan pengamatan serta refleksi untuk setiap siklus. Berdasarkan hasil penelitian ini menunjukkan bahwa ada kenaikan jumlah peserta didik yang aktif hal ini terlihat dari jumlah peserta didik yang aktif berbicara dalam mengungkapkan dan menyanggah pendapat, perbendaharaan kosakata, susunan kalimat, intonasi, pengucapan, dan bekerjasama. Berdasarkan rata-rata kemampuan berbicara bahasa Ingris peserta didik pada siklus I dan siklus II mengalami kenaikan yaitu nilai ratarata 77.81 menjadi 89 dengan nilai tertinggi 87 menjadi 92 dan nilai terendah 75 menjadi 87 pada siklus II.
\end{abstract}

Kata kunci: kemampuan berbicara bahasa Inggris, aktivitas peserta didik, metode debat.

\section{PENDAHULUAN}

Pembelajaran bahasa Inggris di sekolah bertujuan antara lain agar peserta didik mampu berkomunikasi dengan bahasa Inggris baik secara lisan maupun tulis. Hal ini 
ditunjukkan dengan memiliki skill kebahasaan yaitu mendengarkan, berbicara, membaca dan menulis. Halliday, (1978, dalam Materi Pelatihan Terintegrasi Bahasa Inggris) menjelaskan bahwa peserta didik harus mampu berkomunikasi sesuai konteks yang dihadapinya.

Kegagalan atau keberhasilan belajar bahasa Inggris sangat tergantung pada kemampuan dan kesiapan peserta didik untuk mengikuti kegiatan belajar, salah satunya dipengaruhi bagaimana sikap dan minatnya terhadap bahasa Inggris. Adapun sikap dan minat peserta didik dapat diciptakan dan dapat dikembangkan dengan inovasi yang dibuat guru sehingga menarik perhatian dan dapat menumbuhkan minat dan motivasi belajar peserta didik.

Dalam proses pembelajaran diharuskan adanya sebuah komunikasi yang berarti antara guru dan peserta didik, antara peserta didik dan peserta didik sehingga proses pembelajaran benar-benar dapat meningkatkan gairah dan motivasi sehingga dapat menciptakan suasana pembelajaran yang berarti dan menyenangkan. Ghazali (2013: 6) menjelaskan bahwa pelaksanaan "komunikasi riil" di dalam kelas bisa ditentukan oleh faktor-faktor seperti tujuan pelajaran, tingkat kecakapan peserta didik, dan tipe aktivitas permainan peran, wawancara berpasangan, survey/jajak pendapat, atau situasi pemecahan persoalan. Sedangkan Savignon (1987: 20) berpendapat bahwa kelas komunikatif harus melibatkan para pembelajar dalam proses komunikasi yang dinamis dan interaktif dan memberikan kesempatan kepada mereka untuk mengalami bahasa sekaligus menganalisisnya.

Pengalaman belajar harus melibatkan peserta didik secara utuh yakni melibatkan dimensi-dimensi kognitif dan fisik sekaligus afektif. Pengalaman pembelajaran yang bermakna dan menyenangkan dalam belajar bahasa Inggris akan sangat mempengaruhi kondisi minat belajar peserta didik. Sebagian besar peserta didik masih menganggap bahasa Inggris adalah mata pelajaran yang menakutkan, mereka menganggap bahasa Inggris adalah mata pelajaran yang sulit, tak heran jika peserta didik kurang memiliki motivasi dan keinginan untuk mempelajari bahasa Inggris sehingga menyebabkan prestasi belajar bahasa Inggris belum menunjukkan hasil yang memuaskan. Hal ini dapat dilihat dari daftar nilai ulangan harian, nilai tugas, nilai tes semester dan nilai ujian akhir nasional yang belum sesuai dengan harapan guru dan peserta didik. Terlebih dalam hal kemampuan 
berbicara dan berkomunikasi dalam bahasa Inggris masih sangat jauh dari apa yang diharapkan.

Sebagai gambaran pada ulangan harian Materi Descriptive Text kompetensi berbicara tahun pelajaran 2015/2016 dalam tabel ketuntasan sebagai berikut berikut:

Tabel 1.1

Ketuntasan Belajar Tahun Pelajaran 2015/2016

\begin{tabular}{|c|c|c|c|c|c|c|}
\hline Kelas & VII A & VII B & VII C & VII D & VII E & VII F \\
\hline Ketuntasan & $65 \%$ & $69 \%$ & $68 \%$ & $67 \%$ & $69 \%$ & $68 \%$ \\
\hline
\end{tabular}

Dari tabel di atas, ketuntasan belajar masih jauh di bawah rata-rata. Timbulnya masalah tersebut antara lain: (1) Peserta didik masih beranggapan bahwa bahasa Inggris merupakan mata pelajaran yang tidak menarik, sulit, dan membosankan. Ketika proses pembelajaran berlangsung masih ada peserta didik yang kurang bergairah mengikuti proses pembelajaran. Maka kewajiban gurulah untuk menanamkan rasa senang terhadap materi pelajaran bahasa Inggris dengan memberi rangsangan, dorongan, dan motivasi kepada mereka (2) Proses pembelajaran bahasa Inggris kurang kondusif dan inovatif sehingga peserta didik kurang bisa bahkan tidak bisa menerima pembelajaran yang telah diberikan oleh gurunya, yang mengakibatkan hasil belajar bahasa Inggris tidak sesuai dengan yang diharapkan. (3) Rendahnya hasil belajar bahasa Inggris peserta didik juga dikarenakan guru masih sering mengalami kesulitan dalam menyampaikan materi bahasa Inggris kepada peserta didik, (4) Kurangnya variasi guru dalam menggunakan media pembelajaran, teknik pembelajaran, metode pembelajaran, model pembelajaran, dan bahan ajar juga menyebabkan peserta didik kurang bergairah atau kurang semangat dalam menerima pelajaran. Keadaan ini menyebabkan kemampuan peserta didik dalam berkomunikasi bahasa Inggris cenderung menjadi tidak optimal yang berujung pada prestasi belajar peserta didik yang masih rendah.

Agar peserta didik mampu menggunakan bahasa Inggris yang komunikatif maka diperlukan interaksi mengajar yang baik antara guru dengan peserta didik dalam proses pembelajaran. Agar terjalin komunikasi dan interaksi yang baik antar guru dengan peserta didik, maka seorang guru harus memperhatikan kesiapan intelektual peserta didik serta pemilihan metode dan penggunaan media pembelajaran yang tepat dalam proses 
pembelajaran. Keberhasilan peserta didik dalam belajar tergantung pada cara penyajian materi pelajaran, media pembelajaran, teknik pembelajaran, persiapan bahan ajar, dan metode mengajar yang digunakan oleh guru pada proses pembelajaran.

Salah satu model pembelajaran yang diharapkan dapat meningkatkan motivasi dan hasil belajar adalah dengan menggunakan metode pembelajaran debat. Metode debat merupakan salah satu metode pembelajaran yang sangat penting untuk meningkatkan kemampuan berbicara bahasa Inggris. Debat adalah kegiatan adu argumentasi antara dua pihak atau lebih, baik secara perorangan maupun kelompok, dalam mendiskusikan dan memutuskan masalah dan perbedaan. Ketika kita membicarakan debat dalam konteks bahasa Inggris, berarti bahasa yang di gunakan untuk beradu argumen yaitu bahasa Inggris. Debat dapat diartikan pula sebagai silang pendapat tentang tema tertentu antara pihak pendukung dan pihak penyangkal melalui dialog formal yang terorganisasi (Depdiknas, 2001: 2). Dalam debat peserta didik betul-betul teruji kemampuan berpikir terutama kemampuan berbicara dalam menyampaikan pendapat dan menyanggah pendapat orang lain.

\section{KERANGKA TEORI}

Keterampilan berbicara adalah salah satu kemampuan berbahasa yang dimiliki oleh setiap manusia. Hal ini diperolehnya sebagai bentuk peniruan bunyi bahasa. Berbicara merupakan suatu proses penyampaian ide atau gagasan dari pembicara kepada pendengar. $\mathrm{Si}$ pembicara berkedudukan sebagai komunikator sedangkan pendengar sebagai komunikan. Informasi yang disampaiakan secara lisan dapat diterima oleh pendengar apabila pembicara mampu menyampaikannya dengan baik dan benar. Dengan demikian, kemampuan berbicara merupakan faktor yang sangat mempengaruhi kemahiran seseorang dalam penyampaian informasi secara lisan.

Agar pembicaraan itu mencapai tujuan, pembicara harus memiliki kemampuan dan keterampilan untuk menyampaikan informasi kepada orang lain. Hal ini bermakna bahwa pembicara harus memahami betul bagaimana cara berbicara yang efektif sehingga orang lain (pendengar) dapat menangkap informasi yang disampaikan pembicara secara efektif pula. 
Tarigan (2008:15) menyatakan bahwa berbicara merupakan salah satu keterampilan berbahasa yang bersifat produktif lisan karena dalam kegiatan ini orang yang berbicara (pembicara) dituntut dapat menghasilkan paparan secara lisan yang merupakan cerminan dari gagasan, perasaan, dan pikirannya. Sedangkan Canale dan Swain (1980:5) mengemukakan bahwa agar mampu berkomunikasi lisan secara tepat dan efektif, peserta didik harus memiliki kompetensi komunikatif (communicative competence)

Berbicara adalah suatu alat untuk mengomunikasikan gagasan yang disusun serta dikembangkan sesuai dengan kebutuhan si pendengar atau penyimak. Tujuan utama dari berbicara adalah untuk berkomunikasi. Agar dapat menyampaikan pikiran secara efektif, seyogianya si pembicara memahami makna segala sesuatu yang ingin dikomunikasikan. Dia harus mampu mengevaluasi efek komunikasinya terhadap pendengarnya dan harus mengetahui prinsip-prinsi yang mendasari segala situasi pembicaraan, baik secara umum maupun perorangan.

Keterampilan berbicara pada hakekatnya merupakan keterampilan memproduksi arus sistem bunyi artikulasi untuk menyampaiakan kehendak, kebutuhan perasaan, dan keinginan kepada orang lain (Iskandarwarsid, 2008: 240). Scott dan Ytreberg (1990: 30) menyatakan bahwa keterampilan berbicara merupakan keterampilan berbahasa yang sangat ingin dikuasai oleh peserta didik. Di dalam bahasa itu sendiri mereka mampu mengungkapkan emosi, berkomunikasi, dan menggunakan bahasa untuk menghibur diri. Oleh karena itu mereka berharap bisa melakukan hal yang sama ketika mereka belajar bahasa Inggris.

Metode pembelajaran debat termasuk metode pembelaran yang interaktif dan memaksa peserta didiknya untuk berperan aktif dalam proses pembelajaran. Metode pembelajaran debat efektif dalam meningkatkan partisipasi belajar peserta didik. Untuk mengukur kemampuan berbicara, cara yang paling valid adalah dengan menyuruh peserta didik berbicara. Maka dari itu untuk mengukur kemampuan berbicara, perlu diusahakan agar peserta didik benar-benar melakukan kegiatan lisan. Dengan berbicara guru dapat mengetahui tingkat kemampuan berbicara (seperti kemampuan mengutarakan makna yang dimaksud dengan meggunakan kosa kata, tata bahasa, dan lafal secara benar dan lancar). Maka metode debat adalah salah satu metode yang bisa dipakai penilaian peserta didik dalam keterampilan berbicara bahasa Inggris peserta didik. 
Untuk melakukan kegiatan berbicara secara wajar, si pembicara sudah barang tentu memerlukan lawan bicara. Lawan bicara ini juga dapat menjadi tolak ukur apakah pembicaraan si pembicara dapat dimengerti, yang berarti menunjukkan dia berhasil dalam mengkomunikasikan makna yang ingin diutarakannya. Lawan bicara bisa guru ataupun peserta didik. Dalam debat lawan bicaranya adalah kelompok lain yang berperan sebagai kelompok pro dan kelompok kontra.

Materi ajar dipilih dan disusun menjadi paket pro dan kontra. Peserta didik dibagi menjadi beberapa kelompok dan setiap kelompok dibagi menjadi empat orang. Di dalam kelompoknya peserta didik, dua orang mengambil posisi pro dan dua orang mengambil posisi kontra, melakukan perdebatan tentang topik yang ditugaskan. Laporan masingmasing kelompok yang menyangkut kedua posisi pro dan kontra diberikan kepada guru. Selanjutnya guru dapat mengevaluasi setiap peserta didik tentang penguasaan materi dan keterampilan berbicara bahasa Inggris yang meliputi kedua posisi tersebut dan mengevaluasi seberapa efektif peserta didik terlibat dalam prosedur debat.

Dari latar belakang masalah, bahwa di kelas VII C dalam semester dua tahun pelajaran 2015/2016, dapat diidentifikasi sebab-sebab timbulnya masalah sebagai berikut:

1. Kemampuan berbicara bahasa Inggris peserta didik masih belum memuaskan.

2. Peserta didik belum memiliki motivasi yang tinggi dalam pembelajaran bahasa Inggris.

3. Guru masih menggunakan metode konvensional dalam pembelajaran materi descriptive text.

4. Guru belum menggunakan metode pembelajaran yang tepat untuk menumbuhkan motivasi peserta didik dalam proses pembelajaran bahasa Inggris.

\section{METODE}

Penelitian ini dilaksanakan melalui Penelitian Tindakan Kelas (PTK). Prosedur penelitian kelas sebagai berikut; perencanaan, pelaksanaan, pengamatan, dan refleksi. Pelaksanaan tindakan kelas dalam dua siklus, masing-masing siklus dua pertemuan.

Penelitian kelas pada pembelajaran Bahasa Inggris menggunakan metode debat di kelas VII C SMPN 4 Cianjur. Penelitian ini dilaksanakan pada semester II tahun ajaran 2015/2016 pada bulan Pebruari 2016 sampai dengan bulan Maret 2016. 
Pada tahap perencanaan peneliti menganalisa silabus untuk mengetahui kompetensi dasar dan materi pelajaran. Setelah itu membuat RPP, mempersiapkan metode debat, membuat instrument penelitian berupa lembar tes, lembar observasi, dan menentukan observer. Sumber data dalam penelitian kelas ini meliputi peserta didik, teman sejawat, peneliti, dan dokumen. Teknik pengumpulan data yang digunakan yaitu dengan observasi, tes, dan kuesioner. Analisis data yang dilakukan dalam penelitian ini adalah teknik analisis deskriptif yang meliputi data kuantitatif dan data kualitatif. Data kuantitatif diperoleh dari hasil belajar peserta didik sedangkan data kualitatif diperoleh dari hasil observasi.

\section{HASIL DAN PEMBAHASAN}

Penelitian Tindakan Kelas ini dilakukan dalam dua siklus, masing-masing siklus dua pertemuan. Penelitian ini dilaksanakan pada tanggal 13 Pebruari dan 27 Pebruari pada siklus I dan 6 Maret pada siklus II. Kegiatan pembelajaran dalam tindakan kelas ini meliputi kegiatan awal, kegiatan inti, dan kegiatan akhir. Pada kegiatan awal dimulai dengan salam, berdoa, mengkondisikan peserta didik, mengecek kehadiran peserta didik, menyampaikan apersepsi untuk menghubungkan materi yang telah dipelajari peserta didik sebelumnya dengan materi yang akan disampaiakan guru, dan menyampaikan tujuan pembelajaran yang akan dicapai. Dalam kegiatan inti guru melaksanakan pembelajaran dengan menggunakan metode debat. Selama proses pembelajaran guru melakukan observasi dan memberikan penilaian kepada peserta didik, baik penilaian proses maupun penilaian hasil.

Penilaian yang dilakukan dalam proses pembelajaran dengan menggunakan metode debat adalah mengenai aktif berbicara, mengungkapkan pendapat, menyanggah pendapat, kosa kata, susunan kalimat, intonasi, pengucapan, dan bekerja sama. Berdasarkan hasil observasi dan evaluasi yang dilakukan pada siklus I dan siklus II, maka dapat diketahui keaktifan peserta didik dalam proses pembelajaran seperti yang disajikan dalam tabel sebagai berikut:

Data Keaktifan Peserta Didik Siklus I, Siklus II

\begin{tabular}{|l|c|r|c|}
\hline \multirow{2}{*}{ No } & \multirow{2}{*}{ Aspek yang Diobservasi } & \multicolumn{2}{|c|}{ Persentase } \\
\cline { 3 - 4 } & Aktif berbicara & Siklus I & Siklus II \\
\hline 1 & Mengungkapkan pendapat & $78 \%$ & $94 \%$ \\
\hline 2 & & & $69 \%$ \\
\hline
\end{tabular}




\begin{tabular}{|l|c|c|c|}
\hline 3 & Menyanggah pendapat & $69.75 \%$ & $89 \%$ \\
\hline 4 & Kosa kata & $79 \%$ & $89 \%$ \\
\hline 5 & Susunan kalimat & $80 \%$ & $87 \%$ \\
\hline 6 & Intonasi & $82.25 \%$ & $86.5 \%$ \\
\hline 7 & Pengucapan & $82 \%$ & $86 \%$ \\
\hline 8 & Bekerjasama & $80.75 \%$ & $90 \%$ \\
\hline 9 & Rata-Rata & $77.59 \%$ & $88.81 \%$ \\
\hline
\end{tabular}

Data keaktifan peserta didik pada siklus I dan siklus II dapat digambarkan dalam grafik berikut:

Perbandingan Sikap Peserta Didik pada Siklus I dan Siklus II

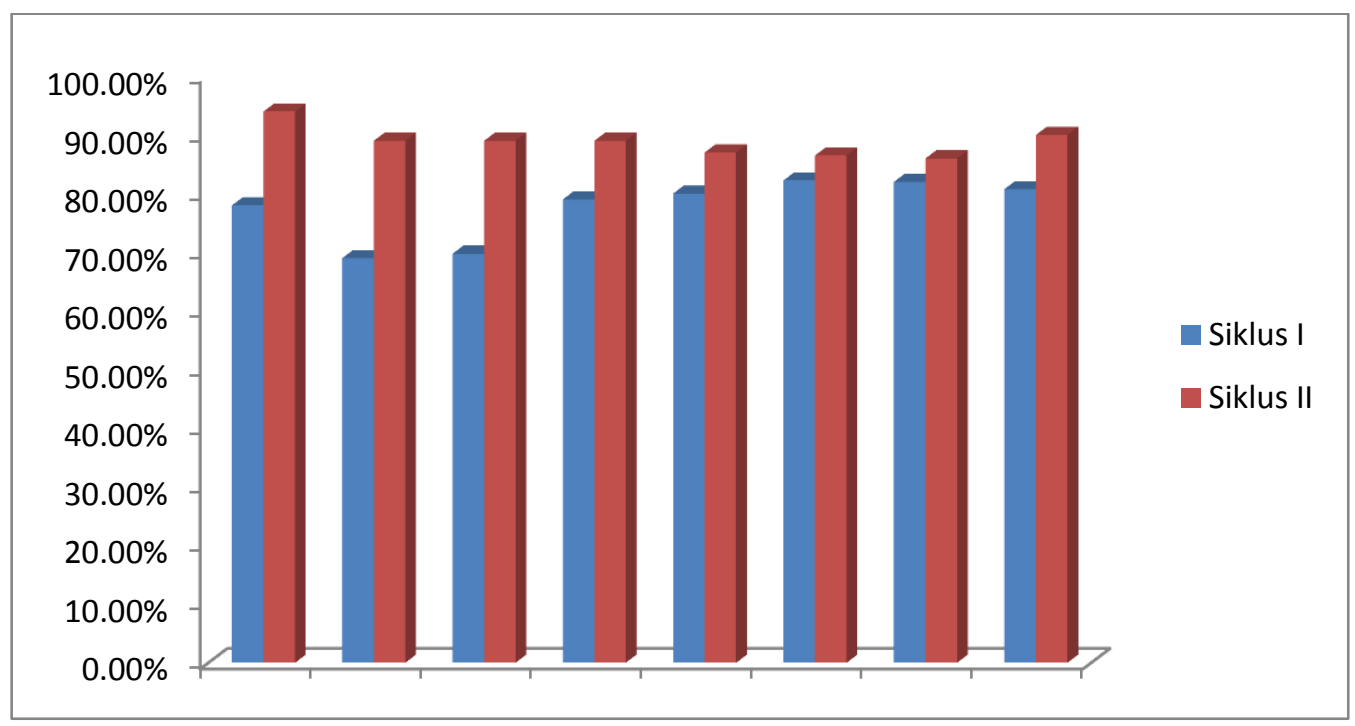

Dari tabel dan grafik keaktifan peserta didik di atas, terlihat bahwa ada kenaikan jumlah peserta didik yang aktif hal ini terlihat dari jumlah peserta didik yang aktif berbicara dalam mengungkapkan dan menyanggah pendapat, perbendaharaan kosakata, susunan kalimat, intonasi, pengucapan, dan bekerjasama.

Adapun hasil nilai kemampuan berbicara bahasa Inggris peserta didik pada siklus I dan siklus II dapat dilihat dari tabel berikut ini:

Perbandingan Hasil Belajar Peserta Didik

Siklus I dan Siklus II

\begin{tabular}{|l|c|c|c|c|}
\hline Siklus I & $\begin{array}{c}\text { Pertemuan } \\
\text { Pertama }\end{array}$ & $\begin{array}{c}\text { Pertemuan } \\
\text { Kedua }\end{array}$ & Rata-Rata & Siklus II \\
\hline Nilai Rata-rata & 75.42 & 81.2 & 77.81 & 89 \\
\hline Nilai Tertinggi & 80 & 87 & 83.5 & 92 \\
\hline Nilai Terendah & 75 & 75 & 75 & 87 \\
\hline Jumlah yang Tuntas & 24 & 35 & - & 38 \\
\hline
\end{tabular}


Jumlah yang Belum Tuntas

Berdasarkan rata-rata kemampuan berbicara bahasa Ingris peserta didik pada siklus I dan siklus II mengalami kenaikan yaitu nilai rata-rata 77.81 menjadi 89 dengan nilai tertinggi 87 menjadi 92 dan nilai terendah 75 menjadi 87 pada siklus II. Maka, dapat disimpulkan pembelajaran dengan menggunakan metode debat dapat meningkatkan kemampuan bicara bahasa Inggris peserta didik kelas VII C. Berdasarkan hasil evaluasi yang dilakukan pada siklus I dan siklus II menunjukkan peningkatan persentase ketuntasan belajar.

\section{SIMPULAN}

Berdasarkan hasil penelitian yang telah dilaksanakan dapat diambil kesimpulan sebagai berikut:

1. Penggunaan metode debat dalam pembelajaran bahasa Inggris dapat meningkatkan kemampuan peserta didik dalam berbicara terutama dalam ketepatan berbahasa (accuracy), pemahaman topik pembicaraan (comprehensibility), cara penyampaian argument, ide/pendapat (method of delivering arguments, ideas/opinions), kefasihan berbahasa (fluency).

2. Hal ini terbukti dari hasil pengolahan data observasi, aktivitas peserta didik meningkat dari $77.59 \%$ menjadi $88.81 \%$. sedangkan perolehan nilai akhir peserta didik meningkat dari 77.81 menjadi 89 .

3. Penerapan metode debat dapat menumbuhkan dan menanamkan kerja sama dan saling menghargai antar teman dalam hal menyikapi perbedaan pendapat.

4. Terjadi interaksi antara peserta didik dengan peserta didik dan antara peserta didik dengan guru.

5. Materi yang diajarkan lebih menarikdan tidak membosankan peserta didik dalam mengikuti proses pembelajaran.

\section{REFERENSI}

Canale, M and Swain, M (1980). Theoretical Bases of Communicative Approaches to Second Language Teaching and Testing. Oxford University. Ghazali Syukur, (2013). Pembelajaran Keterampilan Berbahasa. Bandung, PT 


\section{Refika Aditama.}

Haliday, Materi Pelatihan Terintegrasi Bahasa Inggris.

Iskandarwasid, (2008). Strategi Pembelajaran Bahasa. Rosdakarya: Bandung.

Scott, W.A and Ytreberg, L.H. (1990). Teaching English to Children. Longman.

Tarigan, H.G, (2008). Berbicara sebagai Suatu Keterampilan Berbahasa. Angkasa: Bandung. 